\title{
Gastroscopic follow up of pernicious anaemia patients
}

\author{
S M Sjöblom, P Sipponen, H Järvinen
}

\begin{abstract}
To assess the value of gastroscopic cancer surveillance of patients with pernicious anaemia, 56 patients were re-endoscoped and biopsied after three years. In addition, changes in the density of fundic mucosal endocrine cells were evaluated morphometrically. Two cases $(3.6 \%)$ of early gastric cancer and two cases of small gastric carcinoid tumours $(3.6 \%)$ were detected in addition to the five carcinoids that had been found at the initial endoscopic screening. Nodular argyrophil cell hyperplasia and morphometric density of argyrophil cells were not stable phenomena: nodular hyperplasias regressed in five patients, remained similar in six, and progressed to a small carcinoid tumour in one. Serum gastrin concentrations did not correlate well with changes in the endocrine cell density. Regular endoscopic surveillance for gastric cancer may be beneficial and realistic in young patients with pernicious anaemia while the importance of fundic endocrine cell hyperplasia and that of small gastric carcinoids need further study.

(Gut 1993; 34: 28-32)
\end{abstract}

The basic histopathological phenomenon in pernicious anaemia is severe chronic atrophic gastritis in the proximal acid producing gastric mucosa (type A chronic atrophic gastritis). The atrophic process gradually causes the disappearance of all acid producing parietal cells (total atrophy) and leads to achlorhydria. The antral mucosa is, as a rule, devoid of atrophy and achlorhydria causes hypergastrinaemia through sustained secretion of gastrin from antral $G$ cells because of the loss of negative feedback of acid.'

It has long been known that pernicious anaemia predisposes to the development of gastric adenocarcinoma. ${ }^{23}$ Intestinal metaplasia, achlorhydria, and the formation of carcinogenic $\mathrm{N}$-nitroso compounds are suggested pathogenetic factors. ${ }^{+5}$ However, the prevalence of gastric adenocarcinoma does not exceed $1-3 \%$ in patients with pernicious anaemia, and only $2 \%$ of gastric adenocarcinomas are associated with pernicious anaemia. ${ }^{6-9}$ The need for gastroscopic follow up of pernicious anaemia patients is therefore still debated. ${ }^{10} 11$

More recent findings indicate that hypergastrinaemia associated with pernicious anaemia leads to hyperplasia of fundic endocrine cells. ${ }^{612} 13$ In association with endocrine cell hyperplasia, gastric carcinoid tumours have been observed in $1-7 \%$ of pernicious anaemia patients screened by gastroscopy. ${ }^{69}$

Procedures after the discovery of these tumours have varied from mere follow up to radical gastrectomy..$^{1+16}$ The long term behaviour of small gastric carcinoids and results after their treatment need to be further observed.

In this study we evaluated the findings of follow up gastroscopies performed three years after primary gastroscopic screening of pernicious anaemia patients. The aim of the gastroscopies was to detect possible new gastric tumours, to follow up known gastric carcinoids, and to observe the effect of sustained hypergastrinaemia on fundic endocrine cell changes.

\section{Patients and methods}

\section{PATIENTS}

In 1986, 70 pernicious anaemia patients below the age of 76 years were screened by gastroscopy at the Second Department of Surgery of the Helsinki University Central Hospital. These patients had been treated earlier for pernicious anaemia in the same hospital between 1972 and 1985. The screening showed hyperplastic polyps in 12 patients (17\%), a tubular adenoma in one patient $(1 \%)$, and carcinoid tumours in five patients $(7 \%) .{ }^{8}$ The lesions were found in the atrophic mucosa of the gastric corpus and fundus except for one antral carcinoid tumour. The carcinoids were associated with diffuse and nodular hyperplasia of fundic endocrine cells. ${ }^{6}$ Fifteen additional patients showed nodular hyperplasia of endocrine cells that was not seen in 14 normal controls. No cases of adenocarcinoma were found. The carcinoids were removed by hot biopsy forceps or electrocautery snare.

In 1989 , that is three years after the original gastroscopic screening, the same pernicious anaemia patients were called for a follow up gastroscopy. Fifty four of the original 70 patients attended the examination and two additional patients who had moved from the district had gastroscopy done elsewhere. The mean age of the patients ( 22 men and 34 women) was 60 years (range 27-78 years) at the time of the second gastroscopy. 
ENDOSCOPIC, HISTOLOGICAL, AND LABORATORY METHODS

Several antral and fundic biopsy specimens were taken during the gastroscopies (Olympus GIF-Q 10). In addition to routine biopsy specimens all local changes such as discoloured spots, ulcerative lesions, and polyps were biopsied separately. The specimens were fixed overnight in neutral buffered $10 \%$ formalin and embedded in paraffin wax. The sections $(4 \mu \mathrm{m})$ were stained with haematoxylin and eosin, Alcian blue ( $\mathrm{pH} 2 \cdot 5)$ periodic acid Schiff, and Grimelius techniques.

The diagnosis of carcinoid tumours was based on the typical histological morphology and positive Grimelius staining. ${ }^{17}$ The limit between nodular hyperplasia of endocrine (argyrophil) cells and carcinoid tumours was set at the size of $0.5 \mathrm{~mm}$ according to the classification of Solcia et $a l .{ }^{18}$ Hyperplasia of endocrine cells was called nodular when there were clusters of five or more endocrine cells as suggested by Borch et al. ${ }^{6}$

Argyrophil (Grimelius positive) staining was supposed to detect most fundic endocrine cells. ${ }^{19}$ Morphometric calculation of these cells was performed using an ocular with a square raster plate (64 points) in the microscopic examination (magnification $\times 400$ ). The technique has been described in detail previously. ${ }^{13}$ Briefly, the count of argyrophil cells and the count of raster points coinciding on the mucosa were calculated in areas of standard length and whole thickness of mucosa. Thus it was possible to determine the density of argyrophil cells in arbitrary units of cell count per volume of the mucosa as expressed by the number of conciding raster points. To

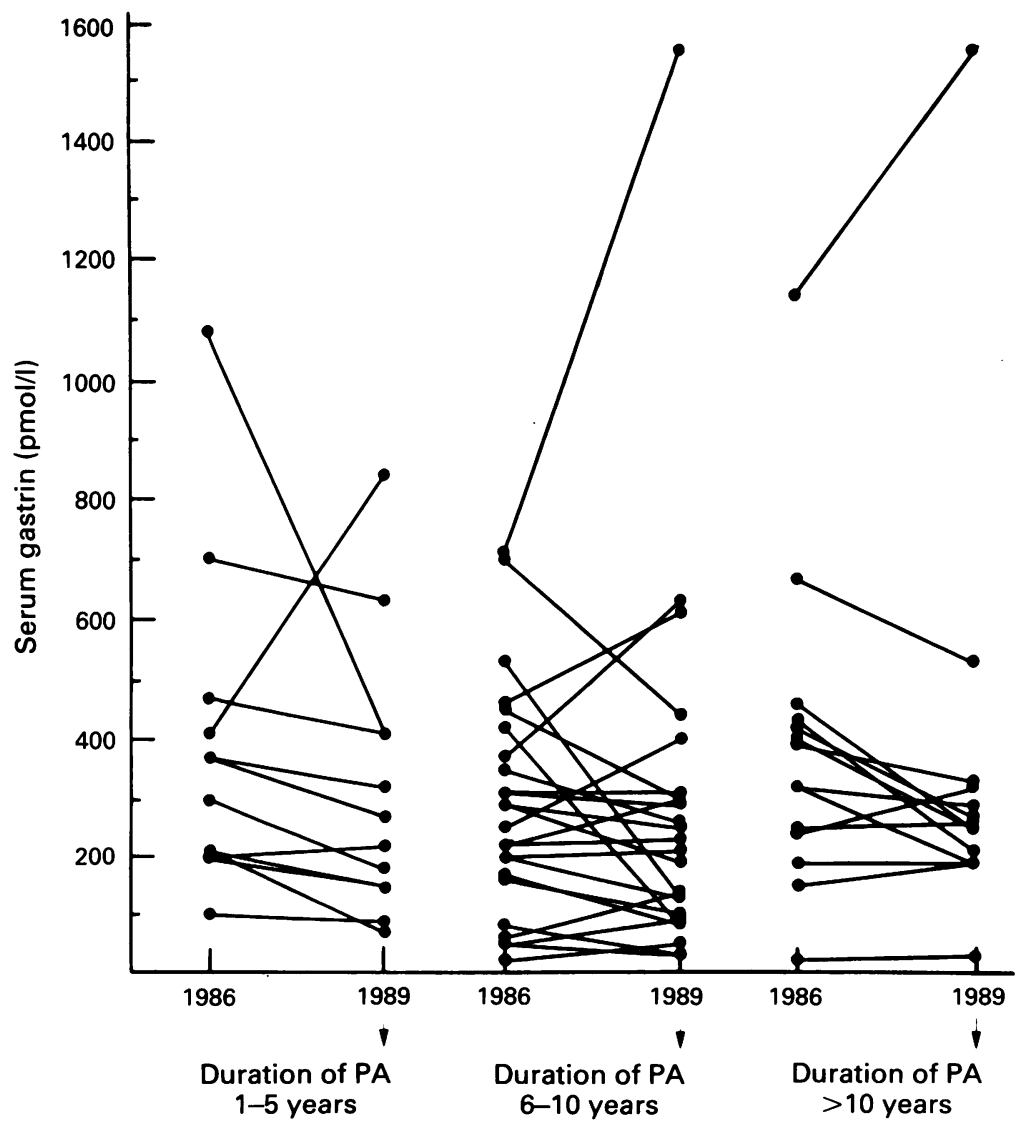

Figure 1: Variations in serum gastrin values in pernicious anaemia $(P A)$ patients who were reexamined after a three year interval. reduce the risk of variable staining intensities, Grimelius staining was performed at the same time for all the specimens of one examination year. During both periods the same person (S-MS) did the counting blindly from the biopsy specimens which randomly represented the fundic (oxyntic) mucosa.

Fasting serum gastrin was measured by a GASK-PR radioimmunoassay kit from Oris Company, France (normal range 5-50 pmol/l). According to the information provided, the antiserum used in the assay stained big-gastrin.

\section{Results}

\section{ADENOCARCINOMA}

The follow up gastroscopies showed two cases of adenocarcinoma. The ages of the patients were 58 and 68 years, and the duration of pernicious anaemia was seven and three years, respectively. One of the carcinomas presented as an ulcer in the distal antrum and the other carcinoma was situated in the distal corpus in a tubular adenoma measuring about $3 \mathrm{~mm}$ in diameter. Both patients underwent subtotal gastrectomy without complications. One of the tumours infiltrated the submucosa and the other was confined to the mucosa. There was no spread to the lymph nodes.

As for possible premalignant changes, all the patients had severe chronic atrophic gastritis in corpus biopsy specimens consistent with the diagnosis of pernicious anaemia, and four patients had slight atrophic changes in antral specimens. Corpus biopsy specimens showed intestinal metaplasia in 49 patients and all four patients with slight atrophic changes in antral specimens also had intestinal metaplasia in the antrum. In 1986 two patients had slight dysplastic changes in random biopsy specimens of the corpus area and six additional patients showed dysplastic changes in antral biopsy specimens. In 1989 the same two patients who had had dysplastic changes in the corpus specimens three years earlier again showed slight dysplasia. Of the six patients with dysplastic changes in the antral biopsy specimens in 1986, two did not participate in the follow up examination and the antral specimens of the remaining four patients were now interpreted as being devoid of dysplastic changes but in one case showing intestinal metaplasia. One additional patient showed slight dysplasia in the antrum. However, the random biopsy specimens in the patients with early gastric cancer did not show dysplasia at either investigation. No severe or moderate dysplasia was seen in any of the patients examined.

\section{CARCINOID TUMOURS}

The previous gastroscopic screening had shown five cases of gastric carcinoids. After the removal of the tumours all these patients had been followed up by gastroscopies every six to 12 months. Two patients showed carcinoid tissue in the electrocautery scars. In one patient the lesion was destroyed by hot biopsy forceps and further biopsy specimens were free from carcinoid infiltration. The other kept showing carcinoid 


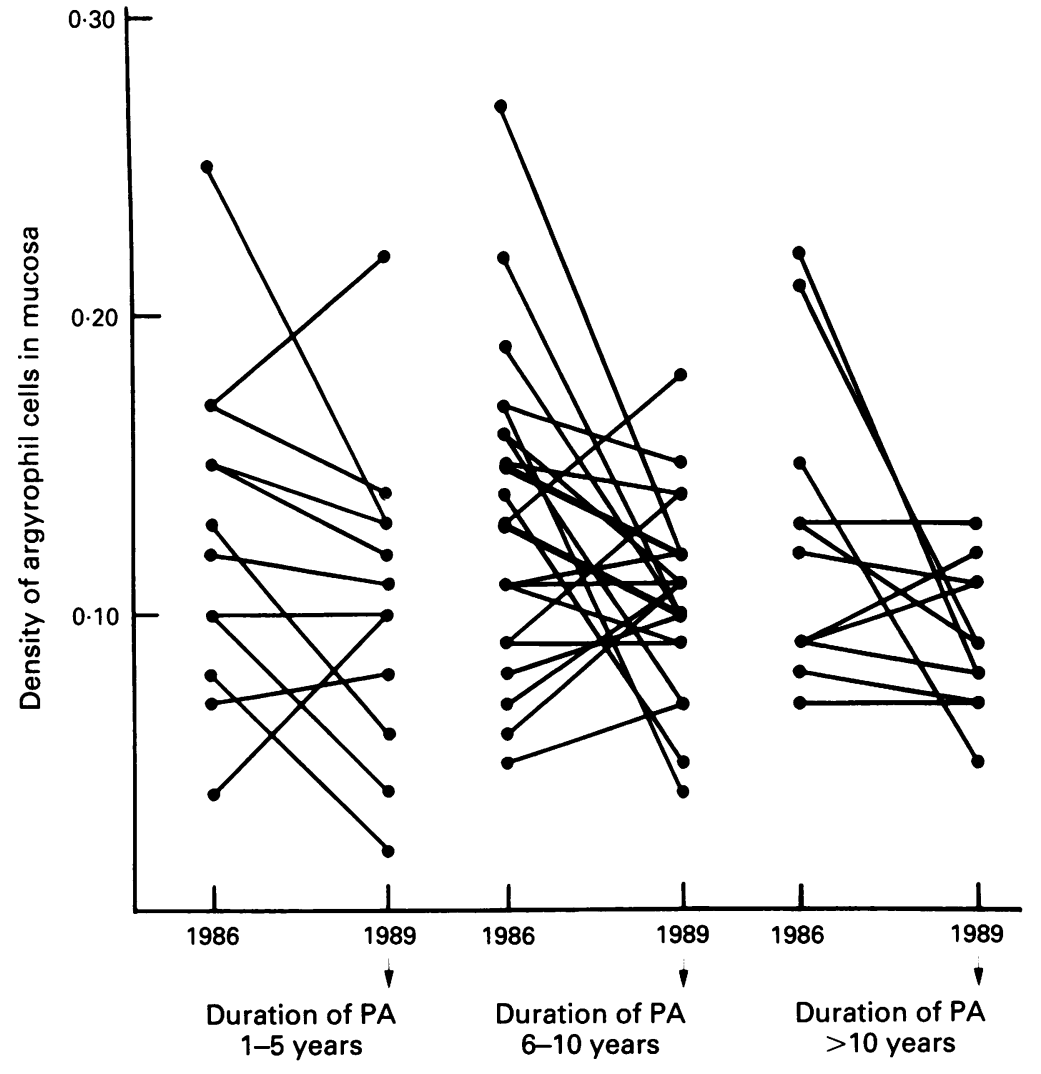

Figure 2: Variations of fundic argyrophil cell densities in pernicious anaemia $(P A)$ patients who were re-biopsied after a three year interval.

infiltration in repeated specimens. Finally, the tumour was excised and antrectomy was performed to reduce the gastrin concentration.

In the present follow up gastroscopy, the former patient harboured a new carcinoid tumour in a different location in the gastric corpus. In addition, two new cases of carcinoid tumours were discovered: one was a polypoid lesion of only $2 \mathrm{~mm}$ in diameter, the other was a

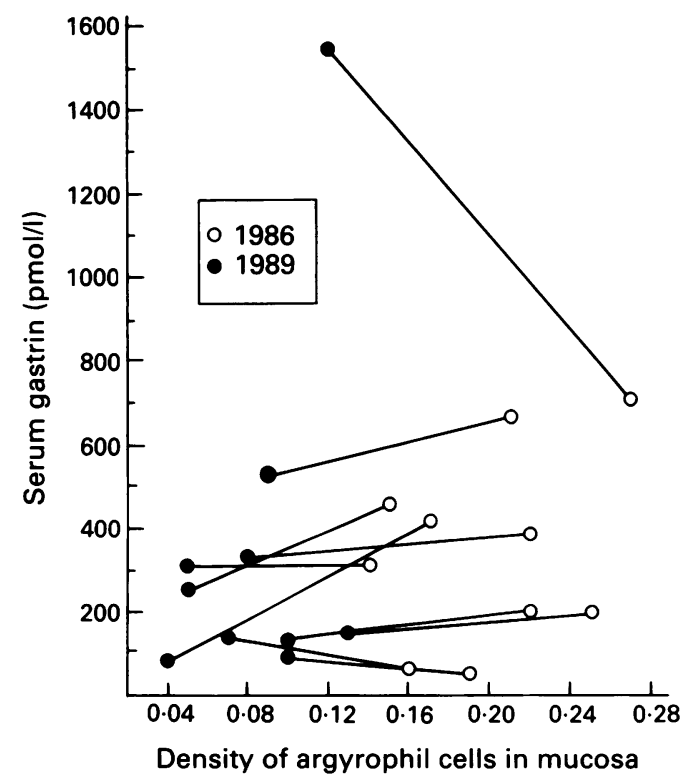

Figure 3: Relations between changes in fundic argyrophil cell densities and serum gastrin values in a selected group of 10 pernicious anaemia patients with the largest changes in the densities during the three years. histological finding as a macroscopic tumour was not evident. It was, however, considered a true neoplasm because of its wide extension $(>0.5$ $\mathrm{mm}$ ) and infiltrative growth pattern in the mucosa. The ages of the patients were 51 and 55 years, the duration of pernicious anaemia 8 and 20 years, and serum gastrin 1550 and $208 \mathrm{pmol} / \mathrm{l}$, respectively.

\section{SERUM GASTRIN}

When comparing the values of 1986 and 1989 , large variations in the gastrin concentrations were exceptional in cases with a moderate increase in serum gastrin $(<400 \mathrm{pmol} / \mathrm{l})$ and common in cases with a considerable increase in serum gastrin $(>400 \mathrm{pmol} / \mathrm{l})(\mathrm{Fig} \mathrm{l})$. There were large differences in gastrin concentrations between individual pernicious anaemia patients at the beginning of the disease, but when pernicious anaemia had lasted more than 10 years, the vast majority of gastrin values were within the range of $200-400 \mathrm{pmol} / \mathrm{l}$.

\section{ARGYROPHIL ENDOCRINE CELLS}

In 1986, the histological specimens of gastric corpus biopsy specimens showed variable amounts of diffuse argyrophil cell hyperplasia in 44 patients, nodular argyrophil hyperplasia in 15 patients, and carcinoid tumours in five patients. Of the 15 patients with nodular argyrophil cell hyperplasia, 12 were biopsied again in 1989. In five patients the nodules had disappeared and histological specimens showed only diffuse hyperplasia of argyrophil cells. In six patients the specimens still showed nodular argyrophil cell hyperplasia, and one patient had developed a carcinoid tumour. This patient also had a serum gastrin concentration that had increased from 710 to $1550 \mathrm{pmol} / \mathrm{l}$. The histological specimens from 1986 are insufficient for analysis of the other patient with a newly developed carcinoid tumour.

The density of argyrophil cells varied considerably from 1986 to 1989 (Fig 2). The largest changes in the densities were not, however, associated with marked variations in serum gastrin concentrations (Fig 3). As a whole the argyrophil cell densities had been reduced by $22 \%$ during the three years in question.

\section{Discussion}

Considering the increased incidence of gastric adenocarcinoma in patients with pernicious anaemia, the present study is in agreement with several previous reports. ${ }^{23}$ According to the Finnish Cancer Registry there were 1244 new cases of gastric adenocarcinoma in Finland in 1984 , at which time the population was $4893748 .{ }^{2021}$ Thus, the yearly incidence rate was $0.03 \%$ for the whole population, and even if it had been adjusted to an age-standardised incidence, the observed incidence of $1 \cdot 2 \%$ would still be more than expected, considering that the uncorrected risk ratio was 40 .

Both the carcinomas observed were still so called early gastric cancers with a favourable prognosis. Regular gastroscopy, if this could be 
achieved, would benefit pernicious anaemia patients. However, most authors agree that it is impractical and expensive to follow up all pernicious anaemia patients. ${ }^{102223}$ There are some known premalignant conditions that might theoretically be used to identify those patients most in need of regular endoscopic follow up. ${ }^{+}$ As for specific premalignant lesions, tubular adenoma in one patient harboured cancer in this study. But in terms of general premalignant changes, almost all the patients with chronic atrophic gastritis had intestinal metaplasia, and the mild dysplastic changes in random biopsy specimens in this study did not coincide with the observed cancers. None, however, had severe dysplasia. Based on this study, it cannot be said that the pernicious anaemia patients with the greatest risk of developing gastric cancer could be identified using intestinal metaplasia or mild dysplasia in random biopsy specimens as a guide. However, the age of onset of pernicious anaemia is more than 70 years in $32 \%$ of cases and more than 60 years in $64 \%$ of cases. ${ }^{8}$ Perhaps it would be possible to screen all pernicious anaemia patients gastroscopically at the time of the diagnosis and follow up at least young patients (those under 60 years of age) endoscopically every three years.

There is no doubt about the malignant potential of adenocarcinoma, but the behaviour of gastric carcinoids is more obscure and needs long term observation. In older series, only large clinically overt gastric carcinoids were discovered, extensive gastric resection was practised, and the five year survival was only about $50 \% .^{15}{ }^{16}$ Recently, endoscopic examinations have increasingly resulted in the discovery of small polypoid gastric carcinoids with a favourable prognosis, and the best treatment of these has been debated..$^{2+25}$ There have been reports of simple gastroscopic monitoring without removal of the tumours ${ }^{14}$ and cases of spontaneous regression of the tumours have been observed. ${ }^{26}$ In a large Japanese series of 100 cases of gastric carcinoid tumours, those less than $1 \mathrm{~cm}$ in diameter were not associated with metastases in any case, those $1-2 \mathrm{~cm}$ in diameter were associated with metastases in $16 \%$ of cases, and those $2-5 \mathrm{~cm}$ in diameter were associated with metastases in $33 \%$ of cases. ${ }^{27}$ On the basis of these and similar findings, it has been suggested that in cases of small tumours up to $1 \mathrm{~cm}$ in diameter, endoscopic removal or local excision would be sufficient, but that larger or numerous carcinoid tumours should be treated by gastric resection or gastrectomy with removal of regional lymph nodes. ${ }^{152728}$ The role of antrectomy in these apparently gastrin dependent tumours is still obscure, but there are reports of regression of fundic carcinoids after antrectomy and subsequent return to normal serum gastrin concentrations. ${ }^{29} 30$

In our series, we also treated multiple gastric carcinoids endoscopically, with gastroscopic removal of all individual carcinoid polyps. However, with very large numbers of carcinoid polyps endoscopic removal would be impractical. In one of our patients endoscopic removal of the carcinoid failed and local excision with accompanying antrectomy was performed.
Other patients were treated endoscopically and during the follow up of three years no residual tumours were observed in the polypectomy scars after complete removal of the primary tumours had been accomplished. One patient developed a polypoid carcinoid but it was in a new location in the stomach. However, the follow up period of three years is relatively short.

The stability of gastric carcinoids and hyperplastic endocrine cell changes in the gastric corpus of pernicious anaemia patients has not been extensively studied. It is generally assumed that hypergastrinaemia predisposes to the development of gastric carcinoids through progressive hyperplastic changes of fundic endocrine cells. ${ }^{61214}$ Antrectomy and reduction of gastrin levels had led to regression of gastric carcinoids. ${ }^{290}$ But as mentioned earlier, there has also been regression of gastric carcinoids without such operative intervention. ${ }^{26}$ Recent reports suggest that hyperplasia of fundic endocrine cells is a stable phenomenon in patients with Zollinger-Ellison syndrome and very high serum gastrin concentrations. ${ }^{3132}$ In addition, Roucayrol and Cattan studied fundic biopsy specimens of 18 totally achlorhydric patients, 12 of whom had pernicious anaemia. ${ }^{33}$ Gastroscopies (2-5 per patient) had been performed with the interval between the first and the last endoscopy varying from 11 to 170 months. The severity of argyrophil cell hyperplasia was assessed, based on the number of argyrophil cell clusters per $\mathrm{mm}^{2}$. Out of 12 patients originally presenting with argyrophil cell clusters, nine had an unchanged degree of hyperplasia, two had decreased hyperplasia, and one had increased hyperplasia at the end of the study. ${ }^{33}$

The stability of nodular endocrine cell hyperplasia in the previous studies is different from our findings. In our study, only six patients out of 12 had stable nodular hyperplasia of endocrine cells. In one patient nodular hyperplasia was now associated with a carcinoid tumour, and in five patients the nodules had dissappeared and the biopsy specimens showed only diffuse hyperplasia of fundic endocrine cells. As a whole, argyrophil cell densities were smaller in 1989 than three years earlier, which may be a true time-related change in pernicious anaemia patients or a methodological failure caused by different staining intensities in different years and because of variations in the counting procedure of the cells in spite of the presence of the same observer. The density of argyrophil cells also varied considerably in individual patients without large changes in gastrin concentrations.

There must be other significant factors besides hypergastrinaemia which determine the degree of hyperplasia of fundic endocrine cells in pernicious anaemia. It seems that in addition to a large number of pernicious anaemia patients with stable nodular hyperplasia of fundic endocrine cells, there are patients in whom the hyperplastic change may progress to carcinoid tumours and some in whom it regresses. In addition, all nodules of endocrine cells are perhaps not hyperplastic but related to atrophy of the surrounding structures, since nodules of fundic endocrine cells have also been observed in a recent study in patients with chronic atrophic 
gastritis and normal serum gastrin values. ${ }^{3+}$ In these cases, the nodules may represent passive clumping of non-proliferating endocrine cells in glands in which the non-endocrine epithelial cells have disappeared.

This study was financially supported by the Finnish Foundation for Cancer Research.

l Babior BM, Bunn HF. Megaloblastic anemias. In: Wilson JD Braunwald E, Isselbacher KJ, Petersdorf RG, Martin JB Fauschi AS, et al, eds. Harrison's principles of internal medicine. 12th ed. New York: McGraw-Hill Inc, 1990: 1526

2 Elsborg L, Mosbech J. Pernicious anaemia as a risk factor in gastric cancer. Acta Med Scand 1979; 206: 315-8.

3 Siurala $M$, Lehtola J, Ihamäki T. Atrophic gastritis and its sequelae. Results of 19-23 years' follow-up examinations. Scand 7 Gastroenterol 1974; 9: 441-6.

4 Ruddell WSJ, Bone ES, Hill MJ, Walters CL. Pathogenesis of gastric cancer in pernicious anaemia. Lancet 1978; i: $521-3$.

5 Sipponen P. Intestinal metaplasia and gastric carcinoma. Ann Clin Res 1981; 13: 139-43.

6 Borch K, Renvall H, Liedberg G. Gastric endocrine cell hyperplasia and carcinoid tumors in pernicious anemia Gastroenterology 1985; 88: 638-48.

7 Eriksson S, Clase L, Moquist-Olsson I. Pernicious anaemia as a risk factor in gastric cancer. The extent of the problem. Acta Med Scand 1981; 210: 481-4.

8 Sjöblom S-M, Sipponen P, Miettinen M, Karonen S-L Järvinen HJ. Gastroscopic screening for gastric carcinoids and carcinoma in pernicious anaemia. Endoscopy 1988; 20: 52-6.

9 Stockbrügger RW, Menon GG, Beilby JOW, Mason RR, Cotton PB. Gastroscopic screening in 80 patients with pernicious anaemia. Gut 1983; 24:1141-7.

10 Stockbrügger R. Zur endoskopischen Entdeckung und Kontrolle der chronischen atropischen Gastritis und der perniziösen Anämie. Z Gastroenterol 1986; 24: 430-3

11 Witte S, Lange J, Stolte $M$. Über die Häufigkeit und Bedeutung der Perniziosa-Schleimhautkonstellation im Magen. Z Gastroenterol 1986; 24: 353-6.

12 Borch K, Renvall H, Liedberg G, Andersen BN. Relation between circulating gastrin and endocrine cell proliferation in the atrophic gastric fundic mucosa. Scand $\mathcal{F}$ Gastroenterol 1986; 21 : 357-63.

13 Sjöblom S-M, Sipponen P, Karonen S-L, Järvinen HJ Mucosal argyrophil endocrine cells in pernicious anaemia and upper gastro-intestinal carcinoid tumours. $\mathcal{F}$ Clin Pathol 1989; 42: 371-7.

14 Harvey RF, Bradshaw MJ, Davidson CM, Wilkinson SP, Davies PS. Multifocal gastric carcinoid tumours, achlorhydria, and hypergastrinaemia. Lancet 1985; i: $951-4$.

15 Johansson $\mathrm{H}$, Wilander E. A clinical study of 30 gastric carcinoids. Ups $\mathcal{F}$ Med Sci 1982; 87: 135-42.
16 Lattes R, Grossi C. Carcinoid tumors of the stomach. Cancer 1956; 9: 698-711.

17 Morson BC. Alimentary tract. In: Symmers W St-C, ed. Systemic pathology. Vol III. Edinburgh: Churchill Livingstone, 1987: 280 .

18 Solcia E, Bordi C, Creutzfeld W, Dayal Y, Dayan AD, Falkmer S, et al. Histopathological classification of nonantral gastric endocrine growths in man. Digestion 1988; 41 : antral gastri.

19 Grimelius L, Wilander E. Silver stains in the study of endocrine cells of the gut and pancreas. Invest Cell Pathol 1980; 3: 3-12.

20 Central Statistical Office of Finland. Population 1984. Helsinki: Government Printing Centre, 1986: 25

21 National Board of Health in Finland. Health service 1987. Helsinki: Government Printing Centre, 1989: 108-9.

22 Ottenjann R. Gastroskopische Kontrollen bei atropische Gastritis vom Perniciosa-Typ? Dtsch Med Wochenschr 1985; 110: 896.

23 Schafer LW, Larson DE, Meiton LJ, Higgins JA, Zinsmeister AR. Risk of development of gastric carcinoma in patients with pernicious anemia. A population-based study in Rochester, Minnesota. Mayo Clin Proc 1985; 60: 444-8.

24 Grouls V, Jantzke G. Pickartz H. Mikrokarzinoidose des Magens. Disch Med Wochenschr 1985; 110: 915-9.

25 Hermanek P. Mikrokarzinoidose des Magens. Disch Med Wochenschr 1985; 110: 1233

26 Harvey RF. Spontaneous resolution of multifocal gastric entero-chromaffin-like cell carcinoid tumours. Lancet 1988; i: 821 .

27 Mizuma K, Shibuya H, Totsuka M, Hayasaka H. Carcinoid of the stomach: a case report and review of 100 cases reported in Japan. Ann Chir Gynaecol 1983; 72: 23-7.

28 Borch K, Renvall H, Kullman E, Wilander E. Gastric carcinoid associated with the syndrome of hypergastrinemic atrophic gastritis. A prospective analysis of 11 cases. Am $\mathcal{F}$ Surg Pathol 1987; 11: 435-44.

29 Müller J, Kirchner T, Müller-Hermelink HK. Gastric endocrine cell hyperplasia and carcinoid tumors in atrophic gastritis type A. Am F Surg Pathol 1987; 11: 909-17.

30 Richards AT, Hinder RA, Harrison AC Gastric carcinoid tumours associated with hypergastrinaemia and pernicious tumours associated with hypergastrinaemia and pernicious anaemia - regre

31 Helander HF. Oxyntic mucosa histology in Omeprazoletreated patients suffering from duodenal ulcer or ZollingerEllison syndrome. Digestion $1986 ; 35: 123-9$

32 Lehy T, Mignon M, Cadiot G, Elouaer-Blanc L, Ruszniewsk $\mathrm{P}$, Lewin MJM, et al. Gastric endocrine cell behaviour in Zollinger-Ellison patients upon long term potent antisecretory treatment. Gastroenterology 1989; 96: 1029-40.

33 Roucayrol A-M, Cattan D. Evolution of fundic argyrophil cell hyperplasia in nonantral atrophic gastritis. Gastroenterology 1990; 99: 1307-14.

34 Havu N, Maaroos H-I, Sipponen P. Argyrophil cell hyperplasia associated with chronic corpus gastritis in gastric ulcer plasia associated with chronic corpus gastritis in gastric ulcer
disease. Scand f Gastroenterol 1991; 26 (suppl 186): 90-4. 